\title{
Notes on Contributors, volume 1
}

Faustina Aerts-Doufikar is Professor of Arabic and Islamic Studies at Vrije Universiteit Amsterdam. Her research focuses on cultural transfer and dissemination of literary, religious and artistic motifs from Antiquity into the Islamic world. Her areas of expertise are the oriental Alexander tradition, the Islamic Gog and Magog traditions, Islamic manuscripts, the Susanna motif and popular epics. Between 20122018 she held a VIDI grant research project on the interdisciplinary study of the literary and artistic traditions concerning Alexander the Great in the Islamic world. She has published as author and editor widely on all these topics, including Gog and Magog. The Clans of Chaos in World Literature (ed., Purdue University Press, 2007) and "Alexander the Great in the Syriac and Arabic Tradition: A Hero Without Borders" (In Fictional Storytelling in the Medieval Eastern Mediterranean and Beyond, Brill, 2016).

Armin Bergmeier (MA in art history, Humboldt University, Berlin; PhD in late antique and Byzantine art history, Ludwig-Maximilian University, Munich) is an art historian of late antique, Byzantine, and Western medieval art with focus on the Eastern Mediterranean and Italy. His work explores changes and transformations across cultures, questions of the presence of art works and architecture, and the Byzantine artistic heritage in Venice. Since 2016, he has been Assistant Professor of Art History at the University of Leipzig. He has held research residencies at the Dumbarton Oaks Research Library, the Kunsthistorisches Institut in Florence, and the Centro Tedesco in Venice. In 2019, he was the Andrew W. Mellon Foundation Postdoctoral Fellow at the Center for Byzantine Studies at Boğaziçi University, Istanbul. His first book is entitled Visionserwartungen: Visualisierung und Präsenzerfahrung des Göttlichen in der Spätantike (Reichert Press 2017), and has received the Hans-Janssen award from the Academy of Arts and Sciences in Göttingen.

Philippe Buc was trained in both France (Paris I Sorbonne and EHESS) and the United States (Swarthmore College and University of California at Berkeley). Having first taught at Stanford University (1990-2011), he has been Professor of Medieval History at the University of Vienna since 2011. He is a specialist in the medieval Catholic theology of politics, illustrated by his work L'ambiguïté du Livre (Editions Beauchesne, 1994) and his critical discussion of the relationship of Anthropology and History, The Dangers of Ritual (Princeton University Press, 2001). Building on his last book, Holy War, Martyrdom, and Terror: Christianity, Violence, and the West (University of Pennsylvania Press, 2015), he is currently working on a comparative history of the impact of religions on warfare. 
Ann Christys is an independent scholar trained in Leeds. She studies the historiography of early medieval Spain in Latin and Arabic. In 2015 she published Vikings in the South: Voyages to Iberia and the Mediterranean (Bloomsbury Academic).

Matthias Däumer is a Postdoctoral Research Assistant and (after academic employments at the Universities of Mainz, Gießen, Berlin, and Tübingen) currently teaching medieval literature at the University of Vienna. His research and publications focus mainly on medieval mediality, serial narration, the Arthurian romances, reception of medieval matters in film and comic, and literary journeys to hell. His upcoming second monograph is about the interferences of these journeys with the courtly romances of the 12th and 13th centuries.

Vincent Eltschinger is Professor for Indian Buddhism at the École Pratique des Hautes Études, PSL Research University, Paris. His research work focuses on the religious background, the apologetic dimensions and the intellectual genealogy of late Indian Buddhist philosophy. His publications include numerous books and articles dedicated to various aspects of the Indian Buddhists' polemical interaction with orthodox Brahmanism from Aśvaghoșa to late Indian Buddhist epistemologists such as Śankaranandana. Mention can be made of Penser l'autorité des Écritures (VÖAW, 2007), Caste and Buddhist Philosophy (Motilal Banarsidass Publishers, 2012), Buddhist Epistemology as Apologetics (VÖAW, 2014), Self, No-Self and Salvation (VÖAW, 2013, together with Isabelle Ratié). Vincent Eltschinger, one of the editors of Brill's Encyclopedia of Buddhism, has been teaching at various universities including Budapest, Lausanne, Leiden, Leipzig, Tokyo, Venice, Vienna, and Zurich.

Clemens Gantner is a Postdoctoral Researcher at the Institute for Medieval Research at the Austrian Academy of Sciences in Vienna. He was a collaborator in several significant research projects in Vienna, most notably the HERA project Cultural Memory and the Resources of the Past (2010-2013) and the ERC AdG Project Social Cohesion, Identity and Religion in the Early Middle Ages (2013-2016). His research is centred on early medieval Italy and intra- and intercultural communication around the Mediterranean. One of his research interests is the movement and appropriation of eastern texts and ideas in the early Latin West. Currently, he is preparing a monograph on Louis II, great-grandson of Charlemagne and emperor in Italy in the ninth century. His most important publication is Freunde Roms und Völker der Finsternis (Böhlau, 2014), which deals with the perceptions of Others by the early medieval papacy.

Zsóka Gelle completed her BA in History, BA and MA in Tibetan Studies in Hungary, and obtained her PhD at the University of Vienna. Between 2011-2014 she was a member of the Doctoral College "Cultural Transfers and Cross-Contacts in the Himalayan Borderlands" at the University of Vienna, and her contribution in the 
present volumes is mostly based on the research and fieldtrips she conducted during that time. She worked as a lecturer at Eötvös Loránd University and as a Khyentse Fellow at the Budapest Center for Buddhist Research between 2014-2016. She taught courses on Tibetan religious practice, Tibetan canonical literature and sacred space in Buddhism. Her main research interests lie in the areas of Nyingma tradition, gter ma literature, history of political and religious contacts between Tibet and Nepal in the 17th-18th centuries, mountain cult, and oral history. Presently she is an independent scholar, living in Bad Ischl, Austria, directing the Yolmo Heritage Project supported by Khyentse Foundation.

Cinzia Grifoni was a Postdoc Researcher in the SFB "Visions of Community" project. Therein, she investigated the development of understanding and use of Latin ethnic designations in the medieval West and was responsible for the contents of the online resource "GENS - Group Terminology and Ethnic Nomenclature: A Semantic Database (Latin Europe c. 400-1200)”. The output of the early medieval scriptorium of the Wissembourg monastery is another important focus of her research. She has published with Brepols the Glossae in Matthaeum ascribed to Otfrid of Wissembourg (CC CM 200) and written several contributions on early medieval exegetic production at Wissembourg and St. Gall. Currently, she holds a Marie Jahoda Grant from the University of Vienna.

Sebastian Günther is Professor and Chair of Arabic and Islamic Studies at the University of Göttingen. His research focuses on the intellectual heritage of the ArabicIslamic world, in particular the Qur'an, religious and philosophical thought, and Arabic belles-lettres. Furthermore, several of his studies are devoted to Islamic ethics and education. Sebastian Günther is co-editor of the Islamic History and Civilization series (Brill) and a former president of the Union Européenne des Arabisants et Islamisants. Günther's recent publications include the co-edited volumes Roads to Paradise: Eschatology and Concepts of the Hereafter in Islam with Todd Lawson (Brill, 2017) and Die Geheimnisse der oberen und der unteren Welt: Magie im Islam zwischen Glaube und Wissenschaft with Dorothee Pielow (Brill, 2018).

Uta Heil is Professor of Church History at the Protestant Theological Faculty of the University of Vienna since 2015. Her research interests include the apologetic literature of the second century CE; the Trinitarian debate during the fourth and sixth centuries, Christianity in the time of migration and the development of a Sunday culture in Late Antiquity and the early Middle Ages. She is one of the main editors of the Journal of Ancient Christianity (De Gruyter). Currently, she is directing a research project on the "Documents on the History of the Debates on Arianism" and a project on "The Apocryphal Sunday on Late Antiquity and the Early Middle Ages." 
Johann Heiss is Senior Researcher at the Institute for Social Anthropology (ISA) at the Austrian Academy of Sciences in Vienna. After studying Classical Philology and Arabic language he finished his study of Social and Cultural Anthropology 1998 with a dissertation on the first imam of the Yemen and the tribal situation in the tenth century. He carried out field research in Saudi-Arabia (together with Walter Dostal and Andre Gingrich), Yemen (together with Andre Gingrich), Indonesia (with Martin Slama) and Lower Austria. He was project leader of "Shifting Memories, Manifest Monuments", addressing the memory of the Turks in Central Europe (ended in 2013); coordinator on the South Arabian part of the SFB "Visions of Community" project. His most recent publications include "Migrations and Federations: The Origins of the Tribal Federation of Khawlān According to al-Hamdānī” (In The Medieval History Journal, 2018), and, together with Eirik Hovden, "Competing Visions of Community in Medieval Zaydi Yemen” (In Journal of the Economic and Social History of the Orient, 2016).

Eirik Hovden is a Postdoc Researcher at the Department of Foreign Languages, University of Bergen, Norway. After studying Geography, Social Anthropology and Arabic, Hovden wrote his MA thesis on rural water management in north-western Yemen and his doctoral thesis on Zaydī Islamic law and historical practices of religious endowments (waqf) in Yemen, both based on fieldwork in Yemen. From 20122016, he was part of the SFB "Visions of Community" research project, working on medieval South Arabian history, and from 2016-2018 he was part of the HERA project "Uses of the Past in Islamic law" (Exeter, UK), focusing on Zaydī Islamic legal theories of governance. He is co-editor of the VISCOM volume Meanings of Community across Medieval Eurasia, together with Christina Lutter and Walter Pohl (Brill, 2016), and published his monograph on Waqf in Zaydī Yemen. Legal Theory, Codification and Local Practice 2019 with Brill.

Guy Lobrichon was a lecturer at the Collège de France, then Professor of History at the University of Avignon (now emeritus). Amongst numerous publications, he wrote on La Bible au Moyen Âge (Éditions Picard, 2003), Romanesque Burgundy (Éditions Stéphane Bachès, 2013/2015) and collaborated on The New Cambridge History of Christianity. Early Medieval Christianity, c. 600-c. 1100 (Cambridge University Press, 2008), and The New Cambridge History of the Bible. From 600 to 1450 (Cambridge University Press, 2012).

Johannes van Oort is Professor emeritus of Utrecht University and Radboud University and presently Professor of Patristics at the University of Pretoria. He published over 25 books and numerous scholarly articles, mainly on Augustine and Manichaeism, as editor and author. Among his newly published books are Augustine and Manichaeism in the Latin West (ed., Brill, 2001); Zugänge zur Gnosis (ed. together with Christoph Markschies, Leuven, 2012); Augustine and Manichaean 
Christianity (ed., Brill, 2013); Jerusalem and Babylon: A Study into Augustine's City of God (Brill, 2015 [1991]); and Mani and Augustine: Collected Essays on Mani, Manichaeism and Augustine (Brill, 2020). In 2011, he was presented with the Festschrift 'In Search of Truth': Augustine, Manichaeism and other Gnosticism. Studies for Johannes van Oort at Sixty (Brill, 2010/repr. 2017). Among others, he is co-editor of Vigiliae Christianae, the Supplements to VC, the Nag Hammadi and Manichaean Studies, and the Corpus Fontium Manichaeorum funded by the UNESCO, the British Academy, the Australian Academy of the Humanities and the Union Académique Internationale.

James Palmer has taught at the University of St Andrews since 2007 and is presently Professor of History. Before that he taught at the universities of Nottingham and Leicester. He is the author of Anglo-Saxons in a Frankish World 690-900 (Brepols, 2009), The Apocalypse in the Early Middle Ages (Cambridge University Press, 2014), and Early Medieval Hagiography (Arc Humanities, 2018). He has recently edited the volume Apocalypse and Reform from Late Antiquity to the Middle Ages (Routledge, 2018) with Matthew Gabriele.

Stephen J. Shoemaker is Professor of Religious Studies at the University of Oregon. He is a specialist on the history of Christianity and the beginnings of Islam. His primary interests lie in the ancient and early medieval Christian traditions, more specifically in early Byzantine and Near Eastern Christianity. His research focuses on early devotion to the Virgin Mary, Christian apocryphal literature, and Islamic origins. Among his publications are The Apocalypse of Empire: Imperial Eschatology in Late Antiquity and Early Islam (University of Pennsylvania Press, 2018); The First Christian Hymnal: The Songs of the Ancient Jerusalem Church (Brigham Young University, 2018); Mary in Early Christian Faith and Devotion (Yale University Press, 2016); Three Christian Martyrdoms from Early Islamic Palestine (Brigham Young University, 2016) and The Death of a Prophet: The End of Muhammad's Life and the Beginnings of Islam (University of Pennsylvania Press, 2011).

Michael Sommer is Stand-in Professor of New Testament Exegesis and Biblical Hermeneutics at the Ludwig-Maximilian University Munich. Before that he taught at the University of Halle and received his PhD in 2013 from the University of Regensburg. His research focuses on prophetic texts and intertextuality. He is author of several publications on the Revelation of John and editoral board member of TC: A Journal of Biblical Textual Criticism, WiBiLex and Zeitschrift für Neues Testament (ZNT).

Elena Tealdi achieved a PhD in History of Christianism at the Catholic University of Sacro Cuore in Milan. She was a member of the ERC project "Origins of the Vernacular Mode” directed by Pavlína Rychterová at the Institute for Medieval Research at 
the Austrian Academy of Sciences and published the critical edition of John of Rupescissa's Vade mecum in tribulatione, together with Gian Luca Potestà and Robert E. Lerner (Vita e Pensiero, 2015). Her main subjects of research are connected to the history of theology and propheticism in the Middle Ages.

Veronika Wieser is a Postdoctoral Researcher at the Institute for Medieval Research at the Austrian Academy of Sciences and a reader in Medieval History at the University of Vienna. From 2011 to 2015, she has worked as a coordinator and researcher within the SFB "Visions of Community" project. Her research revolves around all aspects of eschatology as well as around ascetic communities, historiography and literary traditions in Late Antiquity and the early Middle Ages. She has recently edited the volume Historiography and Identity: Ancient and Christian Narratives together with Walter Pohl (Brill, 2019) and is co-editor of the series Cultural History of Apocalyptic Thought (De Gruyter) together with Christian Zolles. Currently, she is working on her monograph on the role of the End Times in late antique Christian historiography. 